\title{
HOUSEHOLDS' WILLINGNESS TO PAY FOR THE CONSERVATION OF NOUG: A CASE STUDY
}

\author{
Gemechu ORDOFA JARA ${ }^{1}{ }^{*}$ (D), Wubishet TESHOME GEBRETSADIK ${ }^{2}$, Nesru TEMAM HAJIFATO ${ }^{2}$
}

\author{
Address: \\ ${ }^{1}$ Independent consultant. Addis Ababa, Ethiopia \\ ${ }^{2}$ Ethiopian Biodiversity Institute. P.O Box: 30726. Addis Ababa, Ethiopia \\ * Corresponding author: gemefa2013@mail.com
}

\begin{abstract}
Research background: Crop genetic resource conservation and management requires farmers' financial and labour contribution. Guizotia abyssinica (locally named as 'Noug') is among the oil crops originated from Ethiopia, but currently neglected and poorly managed resource.

Purpose of the article: The purpose of this research to understand farmers' behaviour for conservation program and identify better policy, by examining factors affecting households' willingness to pay (WTP) for conservation Guizotia abyssinica, and by estimating the aggregate welfare contribution of household for the proposed conservation program in West Shewa, Ethiopia.

Methods: A contingent valuation survey, double bound with an open-ended follow-up question was directed on 160 selected rural households using multi-stage sampling method. Probit model is employed to achieve the purpose of this study.

Findings \& Value added: The probit model result showed that factors, such as the amount of credit received, perception of conservation problem, education, frequency of extension contact, proportion of land allocated to Guizotia abyssinica, income from Guizotia abyssinica and income from farm activity have a positive and statistically significant effect on households' WTP. On the other hand, total livestock holding, age of households, and initial bid have a negative and significant effect WTP. The aggregate welfare contribution household was estimated to be 1,718,059 man-days and 23,260,839 Ethiopian Birr per year. Improving farmer's extension contact, training farmers, education and solving financial constraints can increase the farmers Guizotia abyssinica conservation in the study area.
\end{abstract}

Key words: willingness to pay; contingent valuation method; Probit; Ethiopia

JEL Codes: Q6; Q8; Q19

\section{INTRODUCTION}

Ethiopia has been recognised as one of the worldwide diversity hotspots for several crops and medicinal plants (Engels et al., 1991). Among these noug (Guizotia abyssinica), coffee (Coffea arabica), safflower (Carthamus tinctorius), tef (Eragrostis tef), anchote (Coccinia abyssinica), enset (Ensete ventricosum) are originated from Ethiopia (Husen, 2012). Guizotia abyssinica is an oil crop cultivated in Ethiopia as a source of income and livelihood for 800,000 farmers (CSA, 2019). It is also an important edible oil crop constituting more than half of the total oilseed production of the country. Guizotia abyssinica shares $20 \%$ of Ethiopian export earnings next to coffee (Bickford, 2020). In addition, it is source of proteins, carbohydrates; vitamins and fibre that significantly contribute to the human diet and food security (Geleta, 2013). Conservation of crop genetics has considerable social and economic benefits for humans and animals. A crop genetic resource is very important to realize sustainable agriculture being source of food, income and medicine (Lipper and Zilberman,
2005; Jiang et al., 2014). However, sustainable benefit from crop is directly related to conservation and management at community level. Unfortunately, farmers who can get income from Noug seed conserve it in unsustainable manner. Noug seed has been recognized as one of the crop that is not properly conserved in Ethiopia (Tsehay et al., 2020). There is a growing recognition that sustainable crop conservation and improvement on farm and gene bank brings long-lasting benefits, but the users and decision-makers are not adequately identified. As a result, the economic contribution of Noug seed in Ethiopia is declining below the potential because it is not significantly cultivated and not properly managed. Some important crops are neglected because gene bank cannot handle all crops. However, farmers and local community take a big share in saving seed loss (Vernooy et al., 2015). On-farm resource conservation is increasingly recognized as sustainable conservation method for crop genetic diversity (Sthapit et al., 2012; Cheng, 2020). Crop genetic resource conservation and management requires farmers' financial or labour contribution (FAO, 2012). However, Noug seed loss and its value as genetic resource 
for human-wellbeing is not well valued in conservation and management decisions in Ethiopia. Noug crop is underutilized and neglected in Ethiopia because it is characterized by very low yield (Tesfaye et al., 2016). But no comprehensive effort has been applied to systematically conserve and utilize Guizotia abyssinica. In addition, currently there is inadequate basic scientific knowledge on Guizotia abyssinica conservation. The contingent valuation method (CVM) is an important economic technique for the valuation of non-market goods and services (Mitchell and Carson, 1989). The contingent valuation method present hypothetical market scenarios for evaluation of certain intervention or specific program (Mould-Quevedo et al., 2009). In ecological economics, CVM has been used to estimate rice diversity conservation (Pant et al.2011), wilderness and endangered species (Bandara and Tisdell, 2005) and conservation Sinar donkey (Melak et al., 2020). Several studies used willingness to pay approach to assess financial and labour contribution in conservation practices. Gebremariam (2012), used CVM to estimate value of soil and water conservation practices. Hundie (2016), used CVM to measure the value improved water supply services. Ayenew et al. (2019) and Teshome (2020) used CVM for evaluation of improved solid waste management, while Girma et al. (2020), used it for evaluation of lake restoration. Similarly, Endalew and Wondimagegnhu (2019) used CVM to estimate economic value of church forest conservation. Studies also show that farmers are willing to contribute 84 million USD dollars for the conservation program of crop varieties (Tyack and Scasny, 2018). Different socioeconomic and institutional variables like size of total livestock holding, credit and extension contact affect farmers' willingness to pay for communal land (Belay et al., 2020). Furthermore, understanding socioeconomic variables and farmers' behaviours is vital for conservation program and better policy (Friis-Hansen and Sthapit, 2000). There is lack of information on farmer's willingness to support conservation contribute of Noug seed. Therefore, a societal preference on the topic is need to identify by conducting study. This can provide significant input for policymakers in support of informed and evidence-based decision-making on crop conservation in developing countries like Ethiopia. Furthermore, there is no study on household willingness to conserve Noug (Guizotia abyssinica) in the country. Therefore, this study attempted to empirically analyse factors that affect farmers' willingness to pay for Noug conservation using contingent valuation method.

\section{LITERATURE REVIEW}

From stated preference valuation techniques contingent valuation method is a most commonly utilized for valuation of non-market asset (Cho et al., 2008). It is a survey-based method often used for setting money related values on ecological goods and services having no market value (Hanemann, 1994; Carson, 2000). Due to adaptability and the capacity to estimate total economic value of resources, contingent valuation method is acquiring prevalence in the environmental economics.
Economists are interested in total welfare. This measure of welfare is formally expressed in a concept called willingness to pay (WTP). Willingness to pay is defined as the highest price an individual is willing to accept or pay for some goods or services (Breidert, 2007). It is a survey technique that gives the interviewees with imaginary situations about a certain mediation or explicit program which is intended to be evaluated (MouldQuevedo et al., 2009). WTP is monetary measures taken at individual level of economic agent, particularly in a simple form for a desired increase in the good, the maximum amount the agent would be willing to pay to obtain the upgrading, and for a loss, the minimum amount the agent would be voluntarily willing to receive in payment in exchange for accepting the loss.

The approach of measuring willingness to pay using contingent valuation methods has been used in many countries for policy evaluation in areas like improved rural water service provision (Bogale and Urgessa, 2012); valuing natural forest resource (Chen and Jim, 2010; Bogale, 2011; Bakaki and Bernauer, 2016); improved soil conservation practices, conservation on communal lands (Gebremariam, 2012; Kasaye, 2015; Belay et al., 2020); water ecosystem services toward forest conservation (Abdulkarim et al., 2017); valuation of environmental goods and services (Yilma, 2019); forest conservation for water quality protection (Kreye $\boldsymbol{e t} \boldsymbol{a l}$., 2014); drinking water quality and protection (Jordan and Elnagheeb, 1993; Lichtenberg and Zimmerman, 1999); reduced risk of drinking water and ground water pollutants (Shultz and Lindsay, 1990; Kim and Cho, 2002); outdoor recreation (Palmer, 1999; Jim and Chen, 2006; Andrews et al., 2017); economic value wetlands (Bergstrom et al., 1990).

The four major elicitation methods in contingent valuation surveys are bidding game, payment card, and single bounded dichotomous choice and double bounded dichotomous choice. In open-ended question, the maximum willingness to pay asked respondents to value the amenity for which no amounts are given earlier. In bidding game question, individuals are iteratively asked whether they were willing to pay a certain amount or not. The amounts are raised up (or dropped down) based on whether the respondent is willing or not willing to pay the previously offered amount. It ends when the iterations have converged to a point estimate of willingness to pay.

The dichotomous choice asks simple yes or no questions like 'would you be willing to pay x amount?'. The dichotomous choice approach has become the probable method of elicitation for CVM practitioners. This method is usually preferred to enquiring an openended question about willingness to pay (Watson and Ryan, 2007). The double-bounded dichotomous choice is more efficient than single bounded dichotomous choice (Arrow et al., 1993), since it is helpful to address the strategic bias and improve measurable effectiveness over single-limited. Haab and McConnell (2002) stated that yes-yes; no-no response in the double bound dichotomous choice format improves unobservable true willingness to pay. The dichotomous format gained considerable acceptance because of its incentive compatibility and its substantial simplification of the cognitive task faced by 
respondents. Double-bounded dichotomous technique is not free from critics and limitations like starting point bias which occurs when the respondent's WTP is influenced by the suggested initial value. It may arise if the product being valued is not well defined or the respondent may think the true value for the service to be around the starting point (Boyle et al., 1988). Giving a detailed description of the good being valued and the whole purpose of the study can reduce this bias. Hypothetical bias of respondents is that they are not familiar with the scenario presented, their response cannot be taken as their real WTP. This bias can be dropped by a cautious explanation for the respondents. Entire bias happens when the respondent neglects to recognize between the parts of the good product being evaluated and the total group of the goods products into which that part falls. The dichotomous format elicitation method in contingent valuation survey has been employed. To biases was minimized by a careful designing of the survey, proper training of the interviewer, conducting a pilot survey and monitoring and supervision of the survey.

\section{DATA AND METHODS}

\section{The study Area}

This study was conducted in West Shewa Zone of Oromia national regional state, Ethiopia. It has 24 districts. Based on the census conducted in 2007 by the Central Statistical Agency of Ethiopia (CSA), this zone has a population of 2 million, of which $50 \%$ each were male. About $94 \%$ of its population is rural inhabitants. The agroecology of this zone is characterized by $40 \%$ mid altitude, $27 \%$ highland, and $33 \%$ lowland. West Shewa Zone is characterized by mixed crop-livestock farming systems. It's agoecology is suitable for production of crops like tef, Guizotia abyssinica, wheat, maize, barley, faba bean, and chickpea.

\section{Sampling Techniques and sample size Determination}

The multi-stage sampling procedure was employed in order to draw sample households. First, West Shewa zone, from Oromia was selected purposively due to agro ecological potential for Guizotia abyssinica production. Secondly, 4 districts are selected from West Shewa using sample random sampling techniques as shown (Table, 1). Thirdly, using update household list 160 households were selected using Cochran's population correction factors (1977) cited in Bartlett et al., (2001) (Equation 1).

$n=\frac{Z^{2} *(p)(q)}{d^{2}}=\frac{1.96^{2} *(0.12)(0.88)}{0.05^{2}}=160$

Where:

$n$ desired sample size when population greater than 10,000 ;

$Z$ standard normal deviation (1.96 for $95 \%$ confidence level);

$\mathrm{p}$ proportion of population to be included in sample i.e., $\mathrm{p}=0.12$

$\mathrm{q}=1-0.12=0.88$;

$\mathrm{d}$ margin of error $(0.05)$

\section{Data Types, Sources and Method of Data Collection}

Both primary and secondary data was utilized in this study. The primary data was gathered from sample household heads using structured questionnaire through face-to-face interviews in December, 2020. On the questionnaire format, socio-economic characteristics, land use, farmers' attitude and practices in seed conservation and other characteristics were considered. Questionnaire and checklist were prepared and pretested before data collection. Key informants drawn from development agents (DAs) and model farmers were interviewed for indepth qualitative information and triangulating data from the household survey.

Table 1: Sampled distribution of households

\begin{tabular}{lcr}
\hline District & $\begin{array}{l}\text { Total number } \\
\text { of households }\end{array}$ & $\begin{array}{l}\text { Sampled } \\
\text { household's }\end{array}$ \\
\hline Dano & 15,117 & 43 \\
Bako Tibe & 19,531 & 56 \\
Ilu Gelan & 10,689 & 31 \\
Liben Jawi & 10,255 & 30 \\
Total & 55,592 & 160 \\
\hline
\end{tabular}

Source: West Shewa Agriculture office (2020)

\section{Economic valuation method}

To elicit respondents' willingness to pay in cash or contribute a labour CVM was used under a hypothetical scenario of conservation of Guizotia abyssinica. The scenario in CVM includes defining the baseline (status quo) and the proposed improvement(s) in a simple, meaningful and justifiable way (Johnston et al. 2017). First, the current status of Guizotia abyssinica genetic resource is defined. Second, a scenario for a hypothetical market was articulated. The hypothesis to the hypothetical market is 'each individual's reply to hypothetically quantified questions is equivalent with the individual response to the actual market'. Finally, the estimation practice begins by asking respondents the amount they will pay in real money or contribute labour to the scenario formulated in the hypothetical market (Bateman and Willis, 2001; Cawley, 2008). We formulated a hypothetical market called 'on farm Guizotia abyssinica conservation Program'. The hypothetical market has two scenarios: a status quo and an improvement scenario. In the status quo scenario, on farm Guizotia abyssinica conservation program' would work to keep on farm Guizotia abyssinica crop domestication, constant at current levels rather than having Guizotia abyssinica endangering. On the other hand, in the improvement scenario, 'on farm Guizotia abyssinica conservation program' would work to increase the Guizotia abyssinica domestication permanently and to improve its productivity.

\section{Empirical model specification}

The objective of the study is to determine the relationship between the individual characteristics and the probability of household WTP for a randomly offered initial bid values. For a given specified amount of cash payment (financial) and labour that has to be subtracted from a given households' financial and labour endowment for Guizotia abyssinica conservation. Farmers have the 
choice either to accept the pre specified bid or not to accept for the dichotomous choice question of the CVM survey. Probit model was used for binary response $(0,1)$, that is whether households are willing to pay or not for the offered bid to improve conservation of Guizotia abyssinica. Farmers' willingness to pay decision for proposed conservation program can be modelled in a utility framework following Hahnemann (1984) as (Eq. 2).

$U_{i}=U_{i}(M$ or $L, Z$ and $Q)$

\section{Where:}

$U_{i}$ utility of the household; M monetary/cash payment;

$\mathrm{L}$ total labour endowment of the household in a year;

$\mathrm{Z}$ socioeconomic characteristics of the household;

$Q$ improved Guizotia abyssinica conservation perceived by the households.

Furthermore, let us assume that $Q^{*}$ as the improve conservation to Guizotia abyssinica and $Q$ as the conservation before the improved conservation practices for Guizotia abyssinica was undertaken. Then, according to Subanti et al. (2017),

$U_{i}^{1}\left(M-\right.$ bid, $Z, Q^{*}$ or $L-$ bid, $\left.Z, Q^{*}\right)+e_{i} \geq U_{i}^{0}(M-$ bid, $Z, Q^{*}$ or $L-$ bid, $\left.Z, Q^{*}\right)+e_{0}$.

Where:

bid is the initial labour payment per year;

$e_{i}$ and $e_{0}$ are the error terms which are with zero means and independently distributed.

Therefore, the probability that a household will decide to pay for the Guizotia abyssinica conservation is conditional indirect utility function for the proposed intervention is greater than the conditional indirect utility function for the status quo.

The $i^{\text {th }}$ household will be willing to accept the initial bid when $U_{i}^{1} \geq U_{i}^{0}$

Therefore, the choice problem can be modelled as binary response variable $\mathrm{Y}$ (Eq. 4)

$Y_{i}=\left\{\begin{array}{c}1, \text { if } U_{i}^{1}\left(M \text { or } L-\text { bid }, Z, Q^{*}\right)+e_{i} \geq U_{i}^{0} \geq \\ (M \text { or } L-\text { bid, } Z, Q)+e_{0} \\ 0, \text { otherwise }\end{array}\right.$

Following Hanemann (1984), the probit model can be specified as Eq (5).

$Y^{*}=\beta^{\prime} \beta x_{i}+\epsilon_{i}$

$Y_{i}=1$ if $Y^{*} \geq \operatorname{bid} 1$ and $Y_{i}=0$ if $Y^{*}<\operatorname{bid} 1$

Where:

$\beta$ vector of unknown parameters of the model; $x$ is vector of explanatory variables;

$Y^{*}$ unobservable households' actual WTP for Guizotia abyssinica conservation;

$Y_{i}$ discrete response of the respondents for the WTP;

bid $1=$ offered initial bids assigned arbitrarily to the $i^{\text {th }}$ respondents;

$\varepsilon$ unobservable random component d distributed $\mathrm{N}(0, \sigma)$.

\section{Estimation of the Mean Willingness to Pay}

The most general econometric model for the doublebounded data is: $W T P_{i j}=\mu_{j}+\varepsilon_{i j}$.

Where: $W T P_{i j}$ represents the $i^{\text {th }}$ respondent's willingness to pay, and $j=1,2$ represents the first and second answer. The mean for the first and second responses are represented by $\mu_{1}$ and $\mu_{2}$.

Following Greene (2012), a Probit model can be specified as Eq. 6.-Eq. 9.

$Y_{1}^{*}=\beta_{I} x_{i}+\varepsilon_{1}$ and $Y_{2}^{*}=\beta_{2} x_{2 i}+\varepsilon_{2}$

$E\left(\varepsilon_{1} / x_{i}, x_{2}\right)=\mathrm{E}\left(\varepsilon_{2} / x_{i}, x_{2}\right)=0$

$\operatorname{Var}\left({ }^{\varepsilon_{1}} / x_{i}, x_{2}\right)=\operatorname{Var}\left({ }^{\varepsilon_{2}} / x_{i}, x_{2}\right)=1$

$\operatorname{cov}\left(\varepsilon_{1}, \varepsilon_{2} / x_{i}, x_{2}\right)=p$

Where:

$Y_{1}^{*}$ is $i^{\text {th }}$ respondents' unobservable true WTP at the time of the first bid?

WTP $=1$ if $Y_{1}^{*}>$ bid 1 , otherwise zero. $Y_{2}^{*}$ is the $i^{\text {th }}$ respondent implicit underlying point estimate at the time of the second bid is offered.

\section{RESULTS AND DISCUSSION}

Socio demographic characteristics of households

Information on socio-economic, demographic characteristics, knowledge and attitude of the farmers is pertinent to increase in value their WTP to secure biodiversity. As shown in Table 2, out of 160 households interviewed about $97 \%$ were male head and $3 \%$ were female head. The average age for household head was 41 years. The overall mean of family size of household was found to be 7.7 per household. About $27.5 \%$ of the households have no formal education. About 59.38\%, $11.25 \%$ and $2 \%$ attended primary, secondary school and certificate respectively. About $92.5 \%$ of 160 households interviewed are willing to pay for Guizotia abyssinica conservation. In addition, about $90 \%$ were perceived Guizotia abyssinica conservation problem. The average livestock holding of household was cows. The mean land owned by household was 3.78 hectare and the mean of land allocated to Guizotia abyssinica production was 1 hectare. The mean frequency of extension contact for household was 4 times per annum. On an average household received 2,258 Ethiopian birr credit. However, there is no statistically significant difference among the households willing and not willing to pay for conservation. The average annual income from farm activity of household was 58,783 Ethiopian Birr (ETB). The average income from off-farm activity was 3,062.5 Ethiopian Birr. The mean income of households from Guizotia abyssinica production was 9980 Ethiopian Birr. The average distance household from farmer training centre was 4 kilometres.

\section{Willingness to pay for Noug (Guizotia abyssinica) conservation}

The economic value of an item is measured by individual willingness-to-pay for the item. Ask for the people whether they would pay anything or not before asking 
amount of their contribution is the first step in economic valuation (Hanemann and Kanninen, 1996). Subsequently, yes or no inquiries were intended to evaluate the willingness to pay decision of the respondents regarding financial and labour contribution. The study shows that $93.125 \%$ of household respondents were able to pay either financial, labour or both for conservation of Guizotia abyssinica. Among the households willing to pay for conservation, about $93.4 \%$ were able to pay both in cash and in labour, while $2.68 \%, 3.35 \%$ able to pay in cash and in labour, respectively, for Guizotia abyssinica conservation program. The result from contingent valuation study showed that the willingness to pay of households ranges from 50 to 2000 Ethiopian Birr (ETB) per hectare every year towards protection exercises of Guizotia abyssinica. As shown in Figure 1, the number of households' willing to pay decreases as bid gets higher and higher. This was because of the law of demand, which says that quantity demand for goods and service diminishes as cost increases. Based on the result, the mean of households' willingness to pay (465 ETB) was higher than the median (400 ETB), which implies that respondents were willing to pay less than the average WTP.
In addition to the cash payment, labour was used as a payment mechanism to measure the willingness to pay for the conservation of Guizotia abyssinica. After completing the yes-no questions for each formulated bid, the highest contribution of man-days for conservation of Guizotia abyssinica was elicited utilizing open-ended questions. The result also shows that the households' ability to contribute labour was from 10 to 70 man-days per year (Figure 2). The mean (33.4 man-days) and median (30 man-days) of their willingness to contribute work indicates that households are able to contribute labour (in man-days) near the mean of willingness to pay.

\section{Reasons for not being willing to pay}

According to Stevens et al. (1994), clarifications behind zero bids should be interpreted and used in decision making. It is possible to recognize the reasons for households not contribute cash or labour for conservation program. Detecting the protest bids is important for misunderstanding of zero value for conservation program. To well understand zero bids and true zero respondents were done through asking the reason for not contribute for improved conservation program. As shown in (Table 3).

Table 2: Socio demographic characteristics of households $(n=160)$

\begin{tabular}{|c|c|c|c|c|}
\hline \multirow[t]{2}{*}{ Variable name } & \multicolumn{4}{|c|}{ Descriptive statistics (mean and percentage) } \\
\hline & $\begin{array}{l}\text { Total } \\
\text { Mean }\end{array}$ & $\begin{array}{l}\text { Willing } \\
\text { households }\end{array}$ & $\begin{array}{l}\text { Unwilling } \\
\text { households }\end{array}$ & $\begin{array}{l}\text { T-value or } \\
\text { Chi- value }\end{array}$ \\
\hline Age of household head & 41 & 40.75 & 39.85 & 1.3 \\
\hline Sex of household ( 1 for male) & 0.968 & 0.9 & 0.068 & $7.01 * * *$ \\
\hline Family size of household & 7.7 & 7.64 & 6.85 & 0.1571 \\
\hline Perception of conservation problem (1 for yes) & 0.15 & 0.8 & 0.68 & $1.64 *$ \\
\hline Education of household ( 1 for yes) & 0.725 & 0.6812 & 0.044 & $14.94 * * *$ \\
\hline Livestock holding (in TLU) & 5 & 4.34 & 6.272 & $1.89 * * *$ \\
\hline Land allocated for Guizotia abyssinica production in ha & 1.02 & 1.1 & 0.4 & 1.45 \\
\hline Total land owned in ha & 3.78 & 3.87 & 3.0384 & 1.2 \\
\hline Frequency of extension visit per year & 3.987 & 3.87 & 5.30 & 1.12 \\
\hline Amount of credit received in Birr & 2,258 & 2,274 & 2,076 & 1.24 \\
\hline Distance from farmer training centre in $\mathrm{km}$ & 4 & 3.818 & 3.185 & $3.34 * * *$ \\
\hline Income from farm activities in Birr & 58,783 & 62,248 & 19,592 & $2.46 * * *$ \\
\hline Income from off-farm activities in Birr & $3,062.5$ & $3,319.7$ & 153.85 & 1.1 \\
\hline Income from Guizotia abyssinica in Birr & 9,980 & 10,721 & 1,595 & $2.583 * * *$ \\
\hline
\end{tabular}

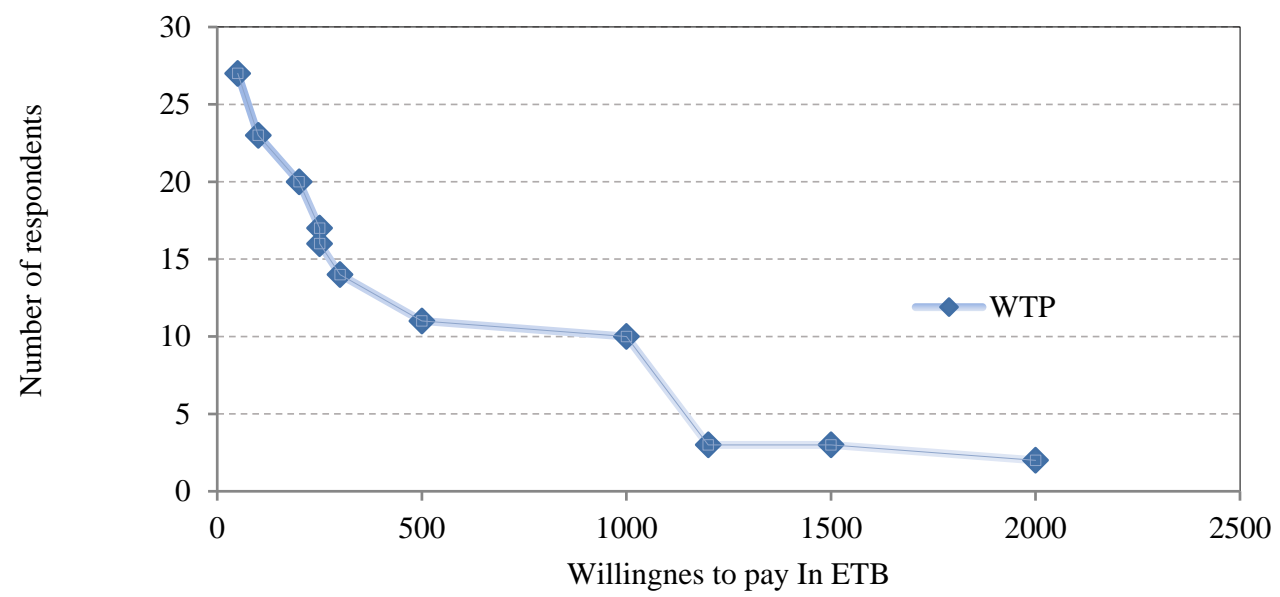

Figure 1. Household willingness to pay in cash (ETB)

Source: Own household survey result (2020) 


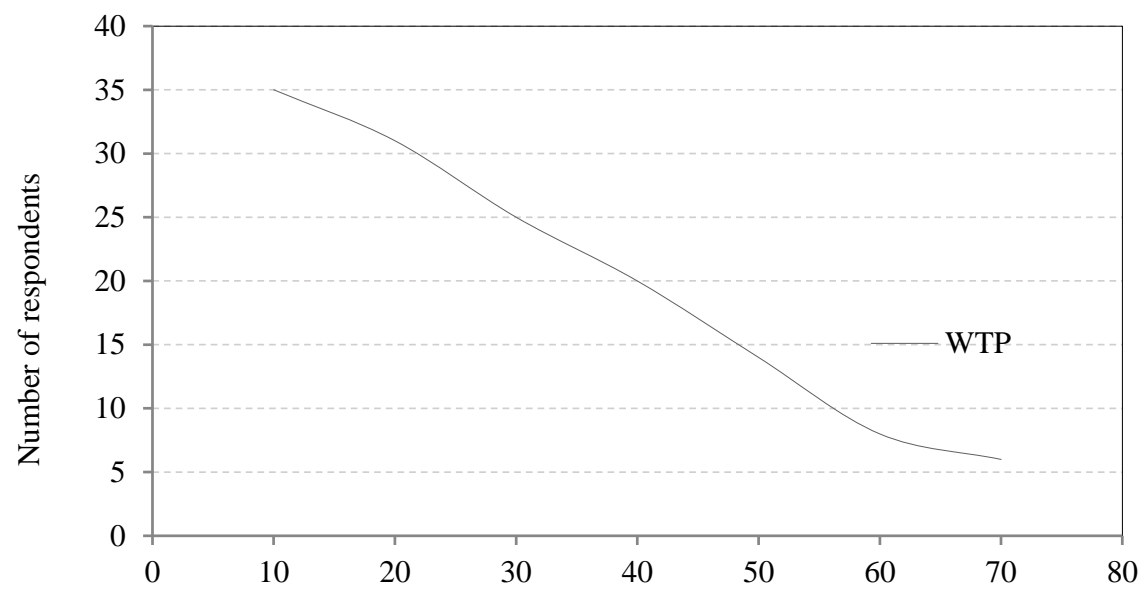

Willingnes to pay in Labour (man-days)

Figure 2. Household willingness to pay in labour (man-days) Source: Own household survey result (2020)

Table 3: Reasons for being unwilling to participate in Guizotia abyssinica conservation Reasons for not being willing to pay Numbers of respondent Frequency

\begin{tabular}{lrr}
\hline Lack of labour and money & 4 & 36.36 \\
Lack of suitable land for Guizotia abyssinica & 3 & 27.27 \\
Lack of trust in conservation & 4 & 36.36 \\
Total & 11 & 100 \\
\hline
\end{tabular}

Source: Household survey result (2020)

These unwilling respondents are supposed to be valid (sensible) zero respondents. The grounds that they demonstrated their willingness to take an interest in the proposed conservation program. However, they couldn't bear the cost of any money for the conservation program. On the other hand, non-willing respondents expressed their justification not being willing to keep seed (27.27\%) and Lack of suitable land for Guizotia abyssinica and lack of trust in the proposed conservation program (36.36\%), respectively and they are supposed to be protest bidders.

\section{Determinants of households' willingness to pay}

To envisage determinants of households' ability to pay in cash and labour contribution for Guizotia abyssinica conservation fifteen independent variables were incorporated in the probit model (Table 4). The chi-square $\left(\chi^{2}\right)$ distribution is used to measure the overall significance of probit model estimation. The result shows that the chi-square distribution is $69.09 \%$ for cash, and $59.33 \%$ for labour (with 15 degree of freedom) at $1 \%$ level of significance. Among the variables in the model, frequency of extension contact, livestock holding, amount of credit received, income from farm activities, income from Guizotia abyssinica production and initial bid were statistically significant variables affecting household willingness to pay in cash. While livestock holding, amount of credit received, education of household head, perception of conservation problem sex of household head and initial bid were significantly affects household's willingness to contribute for conservation program in labour and livestock holding, amount of credit received and initial bid significantly affects household's willingness to pay labour and cash for conservation program.

The frequency of extension contacts of household had a positive and statistically significant effect on WTP. The most likely reason for the statistically significant relationship could be receiving enough access extension contact from development agent increase farmer's knowledge on seed conservation program. Studies indicated that access to agricultural extension affect farmers' private valuations of crop variety (Asrat et al., 2010) and also farmers with more frequent extension more frequently participate on forest restoration program (Mezgebo, 2012). The marginal effect of variable showed that for each additional contact day with extension agents increased the likelihood of farmers WTP for conservation of Guizotia abyssinica by $1.4 \%$, other factors being constant. This finding supported (Belay et al., 2020). The household income from farm activities had a positive effect on their WTP for Guizotia abyssinica conservation. This result may be the household who gain more income from farm sources more management of seed and voluntary pay to conserve the crop. The study showed that amount of money that farmer earned positively affected their choice of any activity (Asrat et al., 2010). When farmers are able to obtain high return from farming, they are not look for a supplementary source of income to satisfy at least the basic needs of their family and they will have allocated more time and money for conservation. The marginal effect of the variable indicated for one thousand increases in household farm income there is 33\% increase their WTP for Guizotia abyssinica conservation, keeping other factors constant. The finding of Ayalneh, (2012) and Mezgebo (2015) show that household farm income 
positively affects willingness to pay for improving of urban and rural water service provision. Income from Guizotia abyssinica production had also a positive effect on the household's willingness to pay cash for its conservation program. The more the farmers received profitable income from Guizotia abyssinica production; the more they allocate lands and more efforts for its conservation. For one thousand increases in income from Guizotia abyssinica production would increase the WTP for Guizotia abyssinica conservation by $1.3 \%$, holding other factors constant. Similar findings indicated that income received from irrigation increased households' willingness to pay for improved irrigation (Alhassan, 2013). On the other hand, the total Livestock holding has a negative effect on the households' willingness to conserve Guizotia abyssinica in both financial and labour contribution. The possession of large numbers of livestock leads to a decrease in households' willingness to pay for Guizotia abyssinica conservation at $1 \%$ level of significance. The probable reason is livestock. It is considered as a measure of wealth in the rural households, but grazing lands for livestock became very critical in Ethiopia. As a result, farmers with large numbers of livestock (TLU) have allocated more land, budget and labour for livestock, than Guizotia abyssinica conservation. For each additional increment of livestock holding (TLU), the probability of households WTP will decrease by $1.2 \%$ in cash and $5.7 \%$ in labour. Studies indicated that there is low production of Guizotia abyssinica production in Guder and Ameya districts of Oromia because they give more focus for livestock production, allocating more land for the production of feed resources (Tesfaye et al., 2016).

The proportion of land allocated to Guizotia abyssinica production had positive and significant effect on WTP in cash at $1 \%$ level of significance. The farm households who have large land were less likely to say no for the offered bid value for conservation program than households with small land. A one hectare allocated for Guizotia abyssinica production would increase the WTP for Guizotia abyssinica conservation by $54.2 \%$, keeping other factors at constant mean. In addition, the amount of credit received was found to have positive and significant effect on the household's WTP for Guizotia abyssinica conservation. As the farmers receive large amount credit they are able to buy seed, labour and rent land for production and conservation of Guizotia abyssinica. A one thousand increase in household credit utilization would increase households' willingness pay in cash by $16.6 \%$ and $6.4 \%$ labour contribution. Farmers' perception about the problem of Guizotia abyssinica conservation has positive and significant effect on households' willingness to contribute labour. The awareness of households on the problem of Guizotia abyssinica seed endangering and its negative impacts motivated farmers to contribute the conservation program. The result show that household willingness for conservation increases by $54 \%$ for perceived farmers than the other counterfactual. This finding supported by Asrat (2004) and Gebremariam, (2012). The probit model has revealed a negative and significant effect of the initial bid at a $1 \%$ and $1 \%$ level of significance for both the cash payment and labour contribution respectively. The result is consistent with the economic theory of the law of demand, which says that quantity demand for goods diminishing as price rise up. The marginal analysis indicated that as the initial bid price rise by one unit, the probability of a household's WTP will drop by $7.1 \%$, ceteris paribus. The marginal effect labour indicates that a one person-days increase for the contribution of the proposed project reduces the probability of being willing to pay by nearly $1.6 \%$. This result supported by Walle (2015), Ayenew and Meride (2015) and Ayana (2017). The education level of the household head had positive and significant relation with household WTP for Guizotia abyssinica conservation. For each year additional increment of household education, the probability to contribute labour for Guizotia abyssinica conservation will increase by $25 \%$, ceteris paribus. Age of the household head had negative effect on the willingness to pay of households for Guizotia abyssinica conservation. The result shows that for 1year increase in farmer's age the WTP to conserve Guizotia abyssinica will decrease by $2.9 \%$, keeping other factors at mean. Studies show that there is negative relationship between age and WTP for investment in environmental protection (Gebremariam, 2012).

\section{Welfare Measure and Aggregation benefit}

The population choice biases, sampling frame bias, sample none response bias and sample selection bias are the four significant issues to be considered with respect to sample design and implementation to have a valid aggregation of benefits (Mitchell and Carson, 1989). A protests zero response was omitted from the analysis and probability of protest zeros was accounted in the assessment of the aggregated benefit. Hence, none of the above biases were expected in the analysis as shown in (Table, 5 and 6), the total economic value in cash and mandays were calculated as the mean WTP by the total number of households in 4 districts of West Shewa. As a result, the aggregate value of Guizotia abyssinica conservation in the study area was 1,718, 059 man-days and 23, 260, 839.15 Ethiopian Birr (ETB) per year.

\section{CONCLUSION AND RECOMMENDATION}

Sustainable development cares for conservation of endangered crops and environmental resources to optimize welfare of present and future generations. Conservation and management of crop genetic resources require farmers' financial and labour contribution. Guizotia abyssinica is one of the oil crops originated from Ethiopia, which is underutilized, neglected and poorly managed. This study was conducted to estimate farmers' willingness to pay for conservation of Guizotia abyssinica in West Shewa zone of Ethiopia. A probit model was employed to analyse the effect of different variables on farmers' willingness to pay for Guizotia abyssinica conservation program. 
Table 4: Factors affect households' willingness to pay for Guizotia abyssinica conservation

\begin{tabular}{|c|c|c|c|c|c|c|}
\hline \multirow[t]{2}{*}{ Variable Name } & \multicolumn{2}{|c|}{ Willingness to pay in ETB } & \multicolumn{4}{|c|}{ Willingness to pay in day man labour } \\
\hline & Coefficient & Standard Error & $\mathrm{dy} / \mathrm{dx}$ & Coefficient & Standard error & $\mathrm{dy} / \mathrm{dx}$ \\
\hline Constants & $9.3 * * *$ & 2.739 & - & 7.012 & 2.455702 & - \\
\hline Age of household & -0.038 & 0.028 & 0.032 & -0.069 & 0.023 & $-0.029 * * *$ \\
\hline Sex of households & -1.187 & 1.022 & -0.095 & 0.426 & 1.45 & 0.012 \\
\hline Family size of household & 0.197 & 0.125 & 0.016 & 0.141 & 0.871 & 0.609 \\
\hline Perception of conservation problem & 1.088 & 0.741 & 0.091 & 1.240 & 0.599 & $0.54 * *$ \\
\hline Education of households & 0.294 & 0.378 & -0.023 & -0.523 & 0.250 & $0.023 * *$ \\
\hline Livestock holding & $-1.478 * * *$ & 0.642 & -0.012 & -1.331 & 0.481 & $-0.0577 * *$ \\
\hline Proportion of land allocated for Guizotia abyssinica production & $0.953 * *$ & 0.542 & -0.790 & -0.046 & 0.261 & -0.002 \\
\hline Total land owned & 0.150 & 0.293 & 0.001 & -0.022 & 0.129 & -0.093 \\
\hline Frequency of extension contact & $0.169 * * *$ & 0.067 & 0.014 & -0.047 & 0.054 & -0.002 \\
\hline Amount of credit received & $0.198 * * *$ & 0.092 & 0.166 & 0.140 & 0.076 & $0.064 * *$ \\
\hline Distance from FTC & 0.420 & 0.233 & 0.035 & 0.030 & 0.164 & 0.013 \\
\hline Income from off-farm activities & 0.060 & 0.062 & 0.005 & 0.034 & 0.045 & 0.148 \\
\hline Income from farm activities & $0.0392 * *$ & 0.0201 & 0.330 & 0.057 & 0.76 & 0.247 \\
\hline Income from Guizotia abyssinica production & $0.152 * *$ & 0.832 & 0.013 & 0.024 & 0.030 & 0.600 \\
\hline Initial Bid value & $-0.02 * * *$ & 0.01 & -0.071 & $-0.21 * * *$ & 0.010 & -0.016 \\
\hline Number of observations & & & 160 & & & 160 \\
\hline LR chi2(15) & & & 69.09 & & & 59.33 \\
\hline Prob > chi 2 & & & 0.000 & & & 0.000 \\
\hline Pseudo R2 & & & 0.668 & & & 56.5 \\
\hline Log likelihood & & & -22.468 & & & -30.62 \\
\hline
\end{tabular}

Note: *,** and *** represents significance level at $10 \%, 5 \%$ and $1 \%$ probability level, respectively.

Source: model output of household survey result (2021); STATA 15 
Table 5: Welfare measures and aggregate benefits by households in ETB

\begin{tabular}{|c|c|c|c|c|c|c|c|c|c|}
\hline $\begin{array}{l}\text { Name of } \\
\text { District }\end{array}$ & $\begin{array}{l}\text { Households } \\
\text { District }\end{array}$ & $\begin{array}{l}\text { Household } \\
\text { sampled }\end{array}$ & $\begin{array}{l}\text { Household } \\
\text { protest }\end{array}$ & & $\begin{array}{l}\% \text { of } \\
\text { Protest } \\
\text { Zeros }\end{array}$ & $\begin{array}{l}\text { Expected } \\
\text { protest }\end{array}$ & $\begin{array}{l}\text { Households with } \\
\text { valid response }\end{array}$ & $\begin{array}{l}\text { Mean } \\
\text { WTP }\end{array}$ & $\begin{array}{l}\text { Total WTP } \\
\text { by district } \\
\text { in ETB }\end{array}$ \\
\hline$\overline{\text { Dano }}$ & 15117 & 43 & & 5 & 0.1163 & 1758 & 13359 & 465 & 6211935 \\
\hline Iln Gelan & 10689 & 31 & & 3 & 0.097 & 1037 & 9654.58 & 465 & 448937 \\
\hline LibenJawi & 10255 & 30 & & 2 & 0.667 & 684 & 9571.33 & 465 & 4450669 \\
\hline Bako Tibe & 19531 & 56 & & 6 & 0.107 & 2089 & 17438.4 & 465 & 8108856 \\
\hline Total & 55592 & 160 & & 16 & 0.1 & 5559.2 & 50033 & & 23260839 \\
\hline
\end{tabular}

Source: Own computation from household survey results (2020)

Table 6: Welfare measures and aggregate benefits by households in labour man-days

\begin{tabular}{lcccrrrrr}
\hline $\begin{array}{l}\text { Name of } \\
\text { district }\end{array}$ & $\begin{array}{l}\text { Households } \\
\text { in district }\end{array}$ & $\begin{array}{l}\text { Household Household } \\
\text { sampled } \\
\text { protest }\end{array}$ & $\begin{array}{l}\% \\
\text { Protest } \\
\text { Zeros }\end{array}$ & $\begin{array}{l}\text { Expected } \\
\text { protest }\end{array}$ & $\begin{array}{l}\text { Households with } \\
\text { valid response }\end{array}$ & $\begin{array}{l}\text { Mean } \\
\text { WTP }\end{array}$ & $\begin{array}{l}\text { Total WTP } \\
\text { by district } \\
\text { man labour }\end{array}$ \\
\hline Dano & 15117 & 43 & 2 & 0.047 & 710.5 & 14413.89 & 33.4 & 481423 \\
Iln Gelan & 10689 & 31 & 4 & 0.13 & 1390 & 9310 & 33.4 & 310954 \\
Liben Jawi & 10255 & 30 & 3 & 0.1 & 1026 & 9230 & 33.4 & 308282 \\
Bako Tibe & 19531 & 56 & 3 & 0.054 & 1055 & 18485 & 33.4 & 617399 \\
Total & 55592 & 160 & 12 & 0.2 & 11118.4 & 51423 & 33.4 & 1718059 \\
\hline
\end{tabular}

Source: Own Computation from household survey results (2020)

The result showed that households' WTP for Guizotia abyssinica conservation was in cash, in labour, or both. Total livestock holding, amount of credit received, frequency of extension contact, proportion of land allocated for Guizotia abyssinica production, income from Guizotia abyssinica production and income from farming activities have positive and significant effect on household WTP for Guizotia abyssinica conservation in cash, while age of households, farmers perception on problem of Guizotia abyssinica conservation, households education and amount of credit received had negative and significant effect on households WTP for conservation in labour contribution. To improve the Guizotia abyssinica conservation, policies should aim to improve frequency of farmers' extension contact, farm household education and solve financial constraints of farmers. Providing training for farmers on land use and management, conservation practice and attitude is also recommended to increase farmer's willingness to pay for Guizotia abyssinica conservation.

Acknowledgments: The authors are grateful to the financial support of the Ethiopian Biodiversity Institute

\section{REFERENCES}

ABDULKARIM, B., YACOB, M. R., ABDULLAH, A. M., \& RADAM, A. (2017). Households' preferences and willingness to pay for watershed services attributes in north Selangor peat swamp forest Malaysia. Asian Journal of Economic Modelling, 5(1), 98-109. doi: $10.18488 /$ journal.8/2017.5.1/8.1.98.109

ALEMAYEHU, N., \& ASHAGRIC, Y. (1991). Linseed, gomenzer and rapeseed agronomy research in Ethiopia. Oilseeds Research afid 000 development in Ethiopia, 104. IAR.

ALEMAYEHU, T. (2014). Smallholder farmer's willingness to pay for improved irrigation water: a contingent valuation study in Koga Irrigation Project, Ethiopia. Journal of Economics and Sustainable Development, 5(19), 5-15. https://core.ac.uk/download/pdf/234646581.pdf

ALHASSAN, M., LOOMIS, J., FRASIER, M., DAVIES, S., \& ANDALES, A. (2013). Estimating farmers' willingness to pay for improved irrigation: an economic study of the Bontanga irrigation scheme in Northern Ghana. Note 1. Journal of Agricultural Science, 5(4), p.31. https://doi.org/10.5539/jas.v5n4p31

ANDREWS, B., FERRINI, S., \& BATEMAN, I. (2017). Good parks-bad parks: the influence of perceptions of location on WTP and preference motives for urban parks. Journal of Environmental Economics and Policy, 6(2), 204-224. https://doi.org/10.1080/21606544.2016.1268543

ARIYO, O. J., \& ALGHAMDI, S. S. (2018). Analysis of combining ability over environments in diallel crosses of maize (Zea mays). Journal of the Saudi Society of Agricultural Sciences, 17(1), 69-78. https://doi.org/10.1016/j.jssas.2016.01.004

ARROW, K., SOLOW, R., PORTNEY, P. R., LEAMER, E. E., RADNER, R., \& SCHUMAN, H. (1993). Report of the NOAA panel on contingent valuation. Federal register, 58(10), 4601-4614. https://edisciplinas.usp.br/pluginfile.php/5021379/mo d resource/content/0/Arow WTP.pdf

ASRAT, P., BELAY, K., \& HAMITO, D. (2004). Determinants of farmers' willingness to pay for soil conservation practices in the southeastern highlands of Ethiopia. Land Degradation \& Development, 15(4), 423-438. https://doi.org/10.1002/ldr.623

ASRAT, S., YESUF, M., CARLSSON, F., \& WALE, E. (2010). Farmers' preferences for crop variety traits: Lessons for on-farm conservation and technology adoption. Ecological Economics, 69(12), 2394-2401. https://doi.org/10.1016/j.ecolecon.2010.07.006 
AYANA, G. Y. (2017). Farmers willingness to pay for soil conservation practices in Gobu Seyo district, Eastern Wollega zone, Oromia national regional state of Ethiopia." International Journal of Agriculture and Environmental Research, 3(3): $2976 . \quad$ doi: 10.22004/ag.econ.262818

AYENEW, B., \& MERIDE, Y. (2015). Labor as a payment vehicle for valuing soil and water conservation practice: an application of contingent valuation method in Abaro-Toga Watershed, Southern Ethiopia. Journal of Economics and Sustainable Development, 6(15), 17-26. https://core.ac.uk/download/pdf/234647174.pdf

AYENEW, B., TILAHUN, A., ERIFO, S., \& TESFAYE, P. (2019). Household willingness to pay for improved solid waste management in Shashemene Town, Ethiopia. African Journal of Environmental Science and Technology, 13(4),

162-171. https://doi.org/10.5897/AJEST2019.2663

BAKAKI, Z., \& BERNAUER, T. (2016). Measuring and explaining the willingness to pay for forest conservation: evidence from a survey experiment in Brazil. Environmental Research Letters, 11(11), 114001.

https://iopscience.iop.org/article/10.1088/17489326/11/11/114001/pdf.

BANDARA, R., \& TISDELL, C. (2005). Changing abundance of elephants and willingness to pay for their conservation. Journal of Environmental Management, 76(1), 47-59. https://doi.org/10.1016/j.jenvman.2005.01.007

BARTLETT, J. E. II, KOTRLIK, J. W., \& HIGGINS, CH. C. (2001). Organizational research: determining appropriate sample size in survey research appropriate sample size in survey research. Information technology, learning, and performance Journal, 19(1), 43.

BATEMAN, I. J., \& WILLIS, K. G. (2001). Valuing environmental preferences: Theory and practice of the contingent valuation method in the US, EU and developing dountries. Resources Policy, 27(1), 57-59. https://doi.org/10.1016/S0301-4207(00)00045-3

BELAY, G., KETEMA, M., \& HASEN, M. (2020). Households' willingness to pay for soil conservation on communal lands: application of the contingent valuation method in north eastern Ethiopia. Journal of Environmental Planning and Management, 63(12), 2227-2245. https://doi.org/10.1080/09640568.2020.1717933

BERGSTROM, J. C., STOLL, J. R., TITRE, J. P., \& WRIGHT, V. L. (1990). Economic value of wetlandsbased recreation. Ecological economics, 2(2), 129147. https://doi.org/10.1016/0921-8009(90)90004-E

BICKFORD, R. (2020). This report contains assessments of commodity and trade issues made by USDA staff and not necessarily statements of official U.S. government policy. USDA.

BOGALE, A. (2011). Valuing natural forest resources: an application of contingent valuation method on AdabaDodola forest priority area, Bale mountains, Ethiopia. Journal of Sustainable Forestry, 30(6), 518-542. https://doi.org/10.1080/10549811.2011.567353
BOGALE, A., \& BERHANU, U. (2012). Households' willingness to pay for improved rural water service provision: application of contingent valuation method in Eastern Ethiopia. Journal of Human Ecology, 38(2), 145-154. DOI:10.1080/09709274.2012.11906483

BOYLE, K. J., WELSH, M. P., \& BISHOP, R. C. (1988). Validation of empirical measures of welfare change: Comment. Land Economics, 64(1), 94-98. https://www.jstor.org/stable/3146613

BREIDERT, C. (2007). Estimation of willingness-to-pay: Theory, measurement, application. Springer Science \& Business Media. https://www.springer.com/gp/book/9783835003996\# aboutBook

CARSON, R. T. (2000). Contingent valuation: a user's guide.

https://econweb.ucsd.edu/ rcarson/papers/CVusersgu ide.pdf

CAWLEY, J. (2008). Contingent valuation analysis of willingness to pay to reduce childhood obesity. Economics \& Human Biology, 6(2), 281-292. https://doi.org/10.1016/j.ehb.2008.05.003

CHEN, W. Y., \& JIM, C. Y. (2010). Resident motivations and willingness-to-pay for urban biodiversity conservation in Guangzhou (China). Environmental management, 45(5), 1052-1064. https://doi.org/10.1007/s00267-010-9478-2

CHENG, W., D’AMATO, A., \& PALLANTE, G. (2020). Benefit sharing mechanisms for agricultural genetic diversity use and on-farm conservation. Economia Politica, 37(1), 337-355. https://doi.org/10.1007/s40888-019-00142-y

CHO, S. H., YEN, S. T., BOWKER, J. M., \& NEWMAN, D. H. (2008). Modelling willingness to pay for land conservation easements: treatment of zero and protest bids and application and policy implications. Journal of agricultural and applied economics, 40(1), 267285. https://doi.org/10.1017/S1074070800028108

CSA (CENTRAL STATISTICAL AGENCY). (2019). The federal democratic republic of Ethiopia central statistical agency agricultural sample survey. Volume $\mathrm{I}$, report on area and production of major crops. https://www.statsethiopia.gov.et/our-survey-reports/

ENDALEW, B., \& WONDIMAGEGNHU, B. A. (2019). Determinants of households' willingness to pay for the conservation of church forests in northwestern Ethiopia: A contingent valuation study. Cogent Environmental $\quad$ Science, 5(1), 1570659. https://doi.org/10.1080/23311843.2019.1570659

ENGELS, J.M.M., HAWKES, J.G., HAWKES, J.G. \& WOREDE, M. (1992). Plant genetic resources of Ethiopia. Cambridge University Press. https://doi.org/10.1017/S0021859600070775

FOOD AND AGRICULTURAL ORGANIZATIONS THE UNITED NATION (FAO). (2012). Cry conservation of animal genetic resources. FAO Animal Production and Health Guidelines No. 12, FAO, Rome. $\quad$ http://www.fao.org/animalproduction/en/

GEBREMARIAM, G. G., \& EDRISS, A. K. (2012). Valuation of soil conservation practices in Adwa Woreda, Ethiopia: A contingent valuation 
study. Journal of Economics and Sustainable Development, 3(13), 97-107.

https://www.iiste.org/Journals/index.php/JEDS/article /view/3494/3519

GELETA, M., \& ORTIZ, R. (2013). The importance of Guizotia abyssinica (niger) for sustainable food security in Ethiopia. Genetic resources and crop evolution, 60(5), 1763-1770. http://link.springer.com/article/10.1007/s10722-0139997-9

GIRMA, H., HUGÉ, J., GEBREHIWOT, M., \& VAN PASSEL, S. (2020). Farmers' willingness to contribute to the restoration of an Ethiopian Rift Valley lake: a contingent valuation study. Environment, Development and Sustainability, 23, 10646-10665. https://doi.org/10.1007/s10668$\underline{020-01076-3}$

GREENE, W. H. (2012). Econometric analysis. 7th ed. New Jersey: Prentice Hall.

HAAB, T. C., \& MCCONNELL, K. E. (2002). Valuing environmental and natural resources: the econometrics of non-market valuation. Edward Elgar Publishing.

https://www.eelgar.com/shop/gbp/valuing-environmental-andnatural-resources-9781840647044.html

HANEMANN, M. (1984). Welfare evaluation in contingent valuation experiments with discrete responses. American Journal of Agricultural Economics, 66, 332-41. http://hdl.handle.net/10.2307/1240800

HANEMANN, W. M. (1994). Valuing the environment through contingent valuation. Journal of Economic Perspectives, 8(4),

$19-43$. https://pubs.aeaweb.org/doi/pdfplus/10.1257/jep.8.4.1 $\underline{9}$

HANEMANN, W. M., \& KANNINEN, B. (1996). The statistical analysis of discrete-response CV Data. Working Paper No. 798. California Agricultural Experiment Station Giannin Foundation of Agricultural Economics, 123.

HUNDIE, S. K., \& ABDISA, L. T. (2016). Households' willingness to pay for improved water supply: application of the contingent valuation method; evidence from Jigjiga town, Ethiopia. http://www.rejournal.eu/sites/rejournal.versatech.ro/fi les/articole/2017-01-03/3411/yhundie.pdf

HUSEN, A., MISHRA, V. K., SEMWAL, K., \& KUMAR, D. (2012). Biodiversity status in Ethiopia and challenges. Environmental pollution and biodiversity, 1 , doi:10.13140/RG.2.1.1788.9121

JIANG, B., ZHOU, X., JIN, S., LI, C. Y., LI, J. L., LI, Y. X., \& ZHANG, Y. M. (2014). Conservation of crop genetic diversity for sustainable agriculture. In Applied Mechanics and Materials, 448, 968-971). Trans Tech Publications Ltd. https://doi.org/10.4028/www.scientific.net/AMM.448 $-453.968$

JIM, C. Y., \& CHEN, W. Y. (2006). Recreation-amenity use and contingent valuation of urban greenspaces in Guangzhou, China. Landscape and urban planning, 75(1-2),

$81-96$

https://doi.org/10.1016/j.landurbplan.2004.08.008

JOHNSTON, R. J., BOYLE, K. J., ADAMOWICZ, W., BENNETT, J., BROUWER, R., CAMERON, T. A., HANEMANN, W.M., HANLEY, N, RYAN, M., SCARPA, R., TOURANGEAU, R., \& VOSSLER, CH. A. (2017). Contemporary guidance for stated preference studies. Journal of the Association of Environmental and Resource Economists, 4(2), 319405. http://dx.doi.org/10.1086/691697

JORDAN, J. L., \& ELNAGHEEB, A. H. (1993). Willingness to pay for improvements in drinking water quality. Water resources research,29(2), 237-245. https://doi.org/10.1029/92WR02420

KASAYE, B. (2015). Farmers willingness to pay for improved soil conservation practices on communal lands in Ethiopia (Case Study in Kuyu Woreda). Doctoral dissertation, Addis Ababa University. http://etd.aau.edu.et/bitstream/handle/123456789/481 6/Belay\%20\%20Kasaye.pdf

KIM, H. J., \& CHO, Y. (2002). Estimating willingness to pay for reduced copper contamination in Southwestern Minnesota. Journal of Agricultural and Resource Economics, 450-463. https://www.jstor.org/stable/40987846?seq=1

KREYE, M. M., ADAMS, D. C., \& ESCOBEDO, F. J. (2014). The value of forest conservation for water quality protection. Forests, 5(5), 862-884. https://doi.org/10.3390/f5050862

LICHTENBERG, E., \& ZIMMERMAN, R. (1999). Information and farmers' attitudes about pesticides, water quality, and related environmental effects. Agriculture, ecosystems \& environment, 73(3), 227-236. doi: 10.1016/S01678809(99)00053-5

LIPPER, L., COOPER, J. C., \& ZILBERMAN, D. (2005). Synthesis chapter: managing plant genetic diversity and agricultural biotechnology for development. In Agricultural Biodiversity and Biotechnology in Economic Development (pp. 457-477). Springer, Boston, MA. Cooper, J., Lipper, L. M., \& Zilberman, D. (Eds.). (2005). Agricultural Biodiversity and Biotechnology in Economic Development. https://doi.org/10.1007/0-387-25409-9_19

MEKONNEN, A. (2000). Valuation of community forestry in Ethiopia: a contingent valuation study of rural households. Environment and Development Economics, 289-308. https://doi.org/10.1017/S1355770X00000188

MELAK, A., BELAYHUN, T., KEFYALEW, E., HAILU, A., MUSTEFA, A., \& ASSEFA, A. (2020). Farmers' willingness to pay for Sinar donkey conservation in selected districts of Metekel and Assosa zones, northwest Ethiopia: a contingent valuation study. Biodiversitas Journal of Biological Diversity, 21(7). https://doi.org/10.13057/biodiv/d210762

MEZGEBO, A. (2012). Households' Willingness to pay for restoring environmental resource: a case study of forest resource from Dire Dawa area, Eastern, Ethiopia. Ethiopian Journal of Economics, 21(2), 3362. 
https://www.ajol.info/index.php/eje/article/view/9152 $\underline{1}$

MEZGGBO, G. K., \& EWNETU, Z. (2015). Households willingness to pay for improved water services in urban areas: A case study from Nebelet town, Ethiopia. Journal of Development and Agricultural Economics, 7(1), 12-19. https://doi.org/10.5897/JDAE2014.0604

MITCHELL, R. C., CARSON, R. T., \& CARSON, R. T. (1989). Using surveys to value public goods: the contingent valuation method. Resources for the Future.

https://econweb.ucsd.edu/ rcarson/papers/UsingSurv eysToValuePublicGoods.pdf

MOULD-QUEVEDO, J. F., GARCÍA-PEÑA, C., CONTRERAS-HERNÁNDEZ, I., JUÁREZCEDILLO, T., ESPINEL-BERMÚDEZ, C., MORALES-CISNEROS, G., \& SÁNCHEZGARCÍA, S. (2009). Direct costs associated with the appropriateness of hospital stay in elderly population. BMC health services research, 9(1), 151. https://doi.org/10.1186/1472-6963-9-151

PALMER, J. F. (1999). Recreational use of wetlands in Juneau, Alaska. In Proceedings of the 1999 Northeastern Recreation Research Symposium, edited by G. Kyle. Gen Tech. Rep. NE-269. Newton Square, PA: USDA, Forest Service, Northeastern Research Station. pp. 62-66

PANT, K. P., GAUTAM, J. C., \& WALE, E. (2011). Valuation of rice diversity in Nepal: a trait-based approach. The Economics of Managing Crop Diversity: On-farm Case Studies from the Genetic Resources Policy Initiative, 4564.https://www.bioversityinternational.org/fileadmin/ user_upload/online_library/publications/pdfs/Crop_di versity_on-farm/3.Rice_diversity_Nepal.pdf

SHULTZ, S. D., \& LINDSAY, B. E. (1990). The willingness to pay for groundwater protection. Water Resources Research, 26(9), 1869-1875. https://doi.org/10.1029/WR026i009p01869

STEVENS, T. H., MORE, T. A., \& GLASS, R. J.. (1994). Interpretation and temporal stability of $\mathrm{CV}$ bids for wildlife existence: a panel study. Land Economics, 70(3): $355-363$. http://www.jstor.org/stable/pdfplus/3146535

STHAPIT, B., SUBEDI, A., JARVIS, D., LAMERS, H., RAO, V. R., \& REDDY, B. M. C. (2012). Community based approach to on-farm conservation and sustainable use of agricultural biodiversity in Asia. Indian Journal of Plant Genetic Resources, 25(1), pp.97-110. https://hdl.handle.net/10568/34630

SUBANTI, S., IRAWAN, B. R. M. B., SASONGKO, G. A. T. O. T., \& HAKIM, A. R. (2017). Economic valuation on change of tourism quality in Rawapening, Indonesia: an application of random utility method. In Journal of Physics: Conference Series, 824(1), 012037. IOP Publishing.

TESFAYE, A., MAMO, T., TESFAYE, M., \& ASSEFA, C. (2016). Production, marketing, processing and technology adoption of noug (Guizotia abyssinica) in Central Ethiopia. Research Report 111. Ethiopian
Institute of Agricultural Research (EIAR). doi:10.13140/RG.2.2.20056.72969

TESHOME, F. B. (2020). Municipal solid waste management in Ethiopia; the gaps and ways for improvement. Journal of Material Cycles and Waste Management, https://doi.org/10.1007/s10163-020-01118-y

TSEHAY, S., ORTIZ, R., JOHANSSON, E., BEKELE, E., TESFAYE, K., HAMMENHAG, C., \& GELETA, M. (2020). New transcriptome-based SNP markers for noug (Guizotia abyssinica) and their conversion to KASP markers for population genetics analyses. Genes, 11(11), 1373. https://doi.org/10.3390/genes11111373

TYACK, N., \& ŠČASNÝ, M. (2018). Social valuation of genebank activities: assessing public demand for genetic resource conservation in the Czech Republic. Sustainability, 10(11), 3997. https://doi.org/10.3390/su10113997

VERNOOY, R., SHRESTHA, P., \& STHAPIT, B. (Eds.). (2015). Community seed banks: origins, evolution and prospects. Routledge. https://cgspace.cgiar.org/bitstream/handle/10568/687 08/Community Seed_Banks.pdf?sequence=2

WALLE, Y. (2015). Local community's valuation of ecological conservation benefits of semien mountain national park. Scholars Journal of Economics, Business and Management 2 (9): 934-943. http://saspjournals.com/sjebm

WATSON, V., \& RYAN, M. (2007). Exploring preference anomalies in double bounded contingent valuation. Journal of Health Economics, 26(3), 463482. doi: $10.1016 /$ j.jhealeco.2006.10.009

YILMA, G. (2019). Wetlands ecosystem service in terms of economic values: A case of Lake Hawassa, southern Ethiopia. Plants and Environment (2019) 1(2): 89-96. https://plantsandenvironment.peri.org.in/article/13/13 -611.pdf 